\title{
Five Species of Parasitic Copepods (Siphonostomatoida: Pandaridae) from the Body Surface of a White Shark Captured in Morro Bay, California ${ }^{1}$
}

\author{
George W. Benz, ${ }^{2}$ Henry F. Mollet, ${ }^{3}$ David A. Ebert, ${ }^{3}$ Corrine R. Davis, ${ }^{4}$ and \\ Sean R. Van Sommeran ${ }^{5}$
}

\begin{abstract}
Five pandarid (Copepoda) species, Dinemoura producta, D. latifolia, Echtbrogaleus coleoptratus, Pandarus bicolor, and Acbtbeinus oblongus, were collected from the external body surface of a white shark, Carcbarodon carcharias, taken from Morro Bay in the northeastern Pacific Ocean off central California. This is the first report of parasitic copepods collected from $C$. carcharias captured in the northeastern Pacific along the West Coast of North America. It is proposed that the species-rich infections of some white sharks may be the result of the wide wanderings of individual sharks through waters inhabited by other elasmobranchs.
\end{abstract}

The white shark, Carcharodon carcharias (Linnaeus, 1758), is a widely distributed coastal and offshore species inhabiting tropical and amphitemperate continental and insular shelves (Compagno 1984a). The species is commonly infected by siphonostomatoids (Copepoda), and globally at least 18 species of these ectoparasites have been reported from C. carcharias (e.g., see Yamaguti 1963, Lewis 1966, Cressey 1967a,b, 1970, Hewitt 1967, 1969, 1979, Kensley and Grindley 1973, Kabata 1979, Love and Moser 1983, Hogans and Dadswell 1985, Pillai 1985, Benz 1986, Oldewage and Smale 1993). To date, all copepod species known to infect white sharks also infect other sharks. Some of these species, e.g., Nemesis lamna Risso, 1826, and

\footnotetext{
I Manuscript accepted 8 April 2002.

${ }^{2}$ Corresponding author: Tennessee Aquarium and Tennessee Aquarium Research Institute, One Broad Street, Chattanooga, Tennessee 37401 (phone: 706-6944666; fax: 706-694-3957; E-mail: GWB@tennis.org).

${ }^{3}$ Moss Landing Marine Laboratories, 8272 Moss Landing Road, Moss Landing, California 95039.

${ }^{4}$ University of California, One Shields Avenue, Davis, California 95616.

${ }^{5}$ Pelagic Shark Research Foundation, S. C. Yacht Harbor, Santa Cruz, California 95060.
}

Pacific Science (2003), vol. 57, no. 1:39-43 (C) 2003 by University of Hawai'i Press All rights reserved
Antbosoma crassum (Abildgaard, 1794), primarily infect close phylogenetic relatives of the white shark (i.e., other members of Lamnidae or Lamniformes [e.g., see Hewitt 1969]). Other species, e.g., Pandarus smitbii Rathbun, 1886, and Echtbrogaleus coleoptratus (Guérin-Méneville, 1837), infect more distantly related inshore or offshore elasmobranchs that share habitat with $C$. carcharias (see Yamaguti 1963, Compagno 1984a,b).

Multiple infections of sharks by siphonostomatoids are common; however, it is unusual (G.W.B., pers. obs.) for an individual shark to be simultaneously infected by more than three species externally or by more than six species in its entirety (i.e., general body surface, olfactory sacs, and buccal and branchial chambers). Hewitt (1979) reported eight siphonostomatoid species from a white shark (three species from the branchial chamber, five species from the general body surface) caught in Pukeria Bay (Pacific Ocean near Wellington, New Zealand). Our report documents the infection of the general body surface of a white shark by five siphonostomatoid species, and it is the first report of parasitic copepods from a white shark captured along the West Coast of North America. Elasmobranch nomenclature and systematics used herein follow Compagno $(1999 a, b)$.

On 23 November 2000 a female white shark (4.33 m total length, $772 \mathrm{~kg}$ ) was caught 
in a halibut gill net set in water $60 \mathrm{~m}$ deep approximately $4.8 \mathrm{~km}$ from shore in Morro Bay, California $\left(35^{\circ} 10^{\prime} \mathrm{N}, 120^{\circ} 40^{\prime} \mathrm{W}\right)$. Upon its landing, the shark was moved and frozen, and later thawed and examined. On at least two occasions during this period copepods were collected from the external body surface of the shark; however, the exact attachment location of all parasites was not recorded. The olfactory sacs, and buccal and branchial chambers of the shark were not thoroughly examined for parasites, and it is possible that during the capture or transport period some ectoparasites may have been dislodged accidentally and lost or removed from the shark by curious bystanders. Collected copepods, fixed in $10 \%$ formalin or $70 \%$ ethanol, were sent to G.W.B. for identification. All of the specimens were identified as pandarids (Siphonostomatoida: Pandaridae), and the species and number of specimens were as follows (all specimens have been retained in the personal collection of G.W.B.).

Dinemoura producta (Müller, 1785): one adult female collected from about the cloaca (possibly on a pelvic fin). Dinemoura producta has been collected from white sharks before this report (Hewitt 1967); however, to our knowledge this is the first such report from the northeastern Pacific along the West Coast of North America. The species is well known from the Atlantic and Pacific Oceans, but according to Hewitt (1967) and Kabata (1979) it has only been reported once (from an unknown host) from the Indian Ocean. This copepod is primarily a parasite of pelagic lamniforms of the families Lamnidae and Cetorhinidae (Hewitt 1967). In northeastern Pacific waters along the West Coast of North America D. producta infects the shortfin mako, Isurus oxyrinchus Rafinesque, 1810 (Heegaard 1945, Cressey 1968, Deets 1985), in addition to the white shark. Geographic records listed by Hewitt (1967) suggest (especially those documenting distribution within the Atlantic Ocean) that $D$. producta is more common in cooler temperate regions than its congener D. latifolia.

Dinemoura latifolia (Steenstrup \& Lütken,
1861): four adult females, one of which was collected from about the cloaca (possibly on a pelvic fin). Dinemoura latifolia has been collected from white sharks before this report (Lewis 1966, Hewitt 1967, Benz 1986); however, to our knowledge this is the first such report from the northeastern Pacific along the West Coast of North America. This copepod has been reported from the Atlantic, Pacific, and Indian Oceans and it is primarily a parasite of pelagic lamnids (Cressey 1967a, Hewitt 1967). In northeastern Pacific waters along the West Coast of North America $D$. latifolia infects the salmon shark, Lamna ditropis Hubbs \& Follett, 1947, and the shortfin mako (Wilson 1935, Cressey 1968, Deets $1985)$ in addition to the white shark.

Echtbrogaleus coleoptratus (Guérin-Méneville, 1837): one immature female collected from about the cloaca (possibly on a pelvic fin). Echtbrogaleus coleoptratus has been reported from white sharks before this report (Yamaguti 1963, Hewitt 1967, 1979); however, to our knowledge this is the first such report from the northeastern Pacific along the West Coast of North America. This copepod has been collected in the Atlantic, Pacific, and Indian Oceans, where it has been reported from squaliforms, lamniforms, and carcharhiniforms, with most reports linking it to pelagic hosts (e.g., see Yamaguti 1963, Kabata 1979, Pillai 1985). In addition to the white shark, in northeastern Pacific waters $E$. coleoptratus has been reported from the leopard shark, Triakis semifasciata Girard, 1854, off California by Russo (1975); from the salmon shark off British Columbia by Bere (1930); from the blue shark, Prionace glauca (Linnaeus, 1758), off California by Pappas (as reported in Love and Moser 1983) and Deets (1985); and from the smooth hammerhead, Sphyrna zygaena (Linnaeus, 1758), off California by Deets (1985).

Pandarus bicolor Leach, 1816: one adult female (partial specimen consisting of cephalothorax and thorax) collected from about the cloaca (possibly on a pelvic fin). Pandarus bicolor has been reported from the white shark before this report (Hewitt 1979); however, to our knowledge this is the first such report 
from the northeastern Pacific along the West Coast of North America. This copepod has been collected in the Atlantic, Pacific, and Indian Oceans, where it has been reported from squaliforms, lamniforms, and carcharhiniforms (Barnard 1955, Yamaguti 1963, Hewitt 1967, Kabata 1979). In addition to the white shark, in northeastern Pacific waters $P$. bicolor has been reported from the piked dogfish, Squalus acantbias Linnaeus, 1758 , by Wilson (1935) and Deets (1985); from the leopard shark by Russo (1975); from the broadnose sevengill shark, Notorynchus cepedianus (Peron, 1807), by Russo (1975) and Ebert (1989); from the tope shark, Galeorbinus galeus (Linnaeus, 1758), by Russo (1975); and from the bluntnose sixgill shark, Hexanchus griseus (Bonnaterre, 1788) by Ebert (1986).

Acbtheinus oblongus Wilson, 1908 (sensu Ho 1975): one young adult and 12 adult females, three of which were collected from a pelvic fin and nine collected from about the cloaca (possibly on the pelvic fins). Cressey (1967a) placed Achtheinus Wilson, 1908, as a junior synonym of Perissopus Steenstrup \& Lütken, 1861, and in doing so he grouped 10 Acbtheinus spp. as one species that he referred to as Perissopus oblongatus (Wilson, 1908). Some lapsus prevented Cressey (1967a) from mentioning an eleventh species of Acbtbeinus-A. armatus (Dana, 1852) (see Oldewage 1992). Ho (1975) resurrected $A c b$ theinus based on specimens that he referred to as $A$. oblongus, the original species epithet spelling of Wilson (1908). Ho (1975) justified this action based on substantial differences between the dorsal plates and leg armature of Achtheinus and Perissopus species. However, to date no one has reexamined type specimens representing the junior synonyms erected by Cressey (1967a) to determine if his action to lump all Acbtheinus spp. as one was well founded. We agree with Ho's (1975) assessment of Acbtheinus, and we further note (G.W.B., pers. obs.) that adult female representatives of Acbtheinus attach to the host by embedding their antennae deeply in the skin whereas those representing Perissopus attach by cementing the enlarged myxal region of their maxillipeds to the host's placoid scales.
In assigning an identity to our specimens and in the remarks that follow we consider $A$. oblongus sensu Ho (1975). Acbtbeinus oblongus has been reported (Barnard 1955) from the white shark in Table Bay (Atlantic Ocean off Cape Town, South Africa); however, we believe this to be the first such report from the northeastern Pacific Ocean off the West Coast of North America. Acbtbeinus oblongus has been collected in the Atlantic, Pacific, and Indian Oceans, where it has been reported from hexanchiforms, squaliforms, pristiophoriforms, lamniforms, carcharhiniforms, rhinobatiforms, and rajiforms, with most reports linking it to benthic-dwelling nearshore hosts (see Yamaguti 1963). In addition to the white shark, in northeastern Pacific waters (including the Gulf of California) A. oblongus has been reported from the broadnose sevengill shark by Wilson (1912); the thresher shark, Alopias vulpinus (Bonnaterre, 1788), by Wilson (1921); the piked dogfish by Deets (1985); the gray smooth hound, Mustelus californicus Gill, 1864, by Ho (1975) and Deets (1985); the brown smooth hound, $M$. benlei (Gill, 1863), by Russo (1975); the sicklefin smooth hound, $M$. lunulatus Jordan \& Gilbert, 1883, by Wilson (1921); the leopard shark by Wilson (1908) and Deets (1985); the smooth hammerhead by Wilson (1944); the shovelnose guitarfish, Rhinobatos productus Girard, 1854, by Ho (1975); and the big skate, Raja binoculata Girard, 1854, by Wilson (1911).

This report and that of Hewitt (1979) demonstrate that although species-rich infections of sharks by siphonostomatoids are generally unusual, they may not be so regarding the white shark. Four of the five copepod species reported herein were also reported by Hewitt (1979) from the collections he examined. Regarding our report, it is possible that a thorough examination of the shark's buccal and branchial chambers would have resulted in collections of two additional siphonostomatoids, Nemesis lamna and Anthosoma crassum, because these species are known to infect these body regions on white sharks collected elsewhere (e.g., see Hewitt 1979), and they are known to exist along the West 
Coast of North America on other lamnids (Love and Moser 1983).

What facilitates the species-rich infections of individual white sharks by siphonostomatoids remains unknown. This phenomenon cannot be explained by the large size that white sharks can attain, because the whale shark, Rbincodon typus Smith, 1828, and the basking shark, Cetorbinus maximus (Gunnerus, 1765), each grow to be considerably larger (Compagno 1984a,b) and yet they are not known to be similarly infected. Furthermore, from a phylogenetic perspective, the basking shark and white shark are close relatives (Compagno 1999a) and their ranges overlap considerably (Compagno 1984a); hence it might be expected that these species would be infected by the same species of copepods. We feel that it is significant that, together, all of the copepod species reported from $C$. carcharias are known to infect a wide phylogenetic and ecological range of elasmobranchs. Based on this and on a recent report (Boustany et al. 2002) of the extremely large home ranges of at least some white sharks that span a variety of inshore and offshore provinces, we propose that the species-rich infections of some white sharks may be the result of the wide wanderings of individual sharks through waters inhabited by other elasmobranchs. Unfortunately, to date too little is known about the biogeography and genetics of the siphonostomatoids that infect the white shark to understand if occurrence patterns and molecular techniques might allow these parasites to be used as biological tags to help in studies of shark movements.

\section{ACKNOWLEDGMENTS}

We thank D. Jessup (California Department of Fish and Game) for use of facilities at the Marine Wildlife Veterinary Care and Research Center; D. Casper (University of California at Santa Cruz) and M. Miller (California Department of Fish and Game) for help with the dissection; S. A. Bullard, C. Schloss, and J. Shaw (all Gulf Coast Research Laboratory) for assistance with the literature; and the Tennessee Aquarium Research Institute for general support.

\section{Literature Cited}

Barnard, K. H. 1955. South African parasitic Copepoda. Ann. S. Afr. Mus. 41:223-312.

Benz, G. W. 1986. Distributions of siphonostomatoid copepods parasitic upon large pelagic sharks in the western North Atlantic. Syllogeus 58:211-219.

Bere, R. 1930. Parasitic copepods from the Vancouver Island region. Fish. Res. Board Can. Misc. Spec. Rep. (Biol.) 259.

Boustany, A. M., S. F. Davis, P. Pyle, S. D. Anderson, B. J. Le Boeuf, and B. A. Block. 2002. Expanded niche for white sharks. Nature (Lond.) 415:35-36.

Compagno, L. J. V. 1984a. Sharks of the world: Hexanchiformes to Lamniformes. FAO Fish. Synop. 125, Vol. 4, Part 1.

1984b. Sharks of the world: Carcharhiniformes. FAO Fish. Synop. 125, Vol. 4, Part 2.

. 1999a. Systematics and body form. Pages 1-42 in W. C. Hamlett, ed. Sharks, skates, and rays: The biology of elasmobranch fishes. The Johns Hopkins University Press, Baltimore.

-. 1999b. Checklist of living elasmobranchs. Pages 471-498 in W. C. Hamlett, ed. Sharks, skates, and rays: The biology of elasmobranch fishes. The Johns Hopkins University Press, Baltimore.

Cressey, R. 1967a. Revision of the family Pandaridae (Copepoda: Caligoida). Proc. U.S. Natl. Mus. 121 (3570): 1-133.

1967b. Caligoid copepods parasitic on sharks of the Indian Ocean. Proc. U.S. Natl. Mus. 121 (3572): 1-21.

1968. Caligoid copepods parasitic on Isurus oxyrinchus with an example of habitat shift. Proc. U.S. Natl. Mus. 125 (3653): 126.

. 1970. Copepods parasitic on sharks from the west coast of Florida. Smithson. Contrib. Zool. 38:1-30.

Deets, G. B. 1985. Copepod and chondrichthyan coevolution: A cladistic analysis. M.S. thesis, California State University at Long Beach, Long Beach, California.

Ebert, D. A. 1986. Biological aspects of the sixgill shark, Hexanchus griseus. Copeia 1986:131-135. 
1989. Life history of the sevengill shark, Notorynchus cepedianus Peron, in two northern California bays. Calif. Fish Game 75:102-112.

Heegaard, P. 1945. Some parasitic copepods from fishes in the Uppsala University collection. Ark. Zool. 35A (18): 1-27.

Hewitt, G. C. 1967. Some New Zealand parasitic Copepoda of the family Pandaridae. N.Z. J. Mar. Freshwater Res. 1:180-264.

1969. Some New Zealand parasitic Copepoda of the family Eudactylinidae. Zool. Publ. Vic. Univ. Wellington 49:131.

1979. Eight species of parasitic copepods on a white shark. N.Z. J. Mar. Freshwater Res. 13:171.

Ho, J.-S. 1975. Parasitic Crustacea. Pages 69-72 in E. D. Lane and C. W. Hill, eds. The marine resources of Anaheim Bay. Calif. Dep. Fish Game Fish Bull. 165.

Hogans, W. E., and M. J. Dadswell. 1985. Parasitic copepods of the white shark (Carcbarodon carcbarius L.) from the Bay of Fundy. Can. J. Zool. 63:740-741.

Kabata, Z. 1979. Parasitic Copepoda of British fishes. The Ray Society, London.

Kensley, B., and J. R. Grindley. 1973. South African parasitic Copepoda. Ann. S. Afr. Mus. 62:69-130.

Lewis, A. G. 1966. Copepod crustaceans parasitic on elasmobranch fishes of the Hawaiian Islands. Proc. U.S. Natl. Mus. 118 (3524): 57-154.

Love, M. S., and M. Moser. 1983. A checklist of parasites of California, Oregon, and Washington marine and estuarine fishes. NOAA Tech. Rep. NMFS SSRF-777.

Oldewage, W. H. 1992. Description of Peris- sopus oblongus (Wilson, 1908) (Copepoda, Pandaridae) from southern African sharks with a first description of the male. Crustaceana (Leiden) 63:44-50.

Oldewage, W. H., and M. J. Smale. 1993. Occurrence of piscine parasitic copepods (Crustacea) on sharks taken mainly off Cape Recife, South Africa. S. Afr. J. Mar. Sci. 13:309-312.

Pillai, N. K. 1985. The fauna of India: Copepod parasites of marine fishes. Zoological Survey of India, Calcutta.

Russo, R. A. 1975. Notes on the external parasites of California inshore sharks. Calif. Fish Game 61:228-232.

Wilson, C. B. 1908. North American parasitic copepods: A list of those found upon the fishes of the Pacific Coast with descriptions of new genera and species. Proc. U.S. Natl. Mus. 35:431-481.

1911. North American parasitic copepods. Descriptions of new genera and species. Proc. U.S. Natl. Mus. 39:625-634. 1912. Descriptions of new species of parasitic copepods in the collections of the United States National Museum. Proc. U.S. Natl. Mus. 42:233-243.

- 1921. New species and a new genus of parasitic copepods. Proc. U.S. Natl. Mus. 59:1-17.

1935. Parasitic copepods from the Pacific Coast. Am. Midl. Nat. 16:776797.

-1944. Parasitic copepods in the United States National Museum. Proc. U.S. Natl. Mus. 94:529-582.

Yamaguti, S. 1963. Parasitic Copepoda and Branchiura of fishes. Interscience Publishers, New York. 